\title{
Interfering Influence of Native German Dialects on the Language of Non-native Dialect Environment: Russian Speech of the German Bilinguals
}

Olga Vladimirovna Baykova, ${ }^{+*}$ Andrey Viktorovich Kazakov, ${ }^{\dagger}$ Vladimir Alexandrovich Banin, ${ }^{\dagger}$ Olga Nikolayevna Obukhova, ${ }^{+}$Yilia Valeryevna Berezina, ${ }^{\dagger}$ and Viacheslav Nikolaevich Onoshko ${ }^{\dagger}$

\section{Abstract}

The problem of interference is one of the most complex issues related to language interaction, so it is especially important to investigate its workings on the example of the language of Russian Germans in the Kirov region. The article realises the historical and linguocultural approaches to the study of the interrelationship between folk-colloquial speech and the traditional culture of Russian Germans, residing on the territory of the Kirov region. The authors present the results of an in-depth analysis of interference features in the Russian speech of German bilinguals under the influence of the German language and its dialects, namely, the phonetic, lexical and grammatical features that occur under the influence of interference with the German language. The Russian speech of German bilinguals is heterogeneous and varies from "virtually without an accent" to "unnatural" for Russian monolingual hearing. The interaction of the Russian and German languages in the speech of German bilinguals resulted in the increased invasion of the norms of one language system into the framework of another language. This leads to the so-called levelling of the interacting languages. In other words, we see the emergence of a third - intermediate system that does not coincide either with the German or Russian languages and performs in the bilingual consciousness an adaptive function to the environment language. This study contributes to German dialectology, enriching both the theory and typology of island dialects, which retain archaic features and the theory and practice of scientifically grounded language policy and language preservation.

Keywords: Russian Germans of the Kirov Region, Native German Dialects on the Language of Non-native Dialect Environment, Russian Speech of the German Bilinguals, Interference at all Levels of the Language, Mixing of Languages

\footnotetext{
${ }^{+}$Vyatka State University, 610000, Russia, Kirov, Moskovskaya Street, 36

${ }^{*}$ Corresponding Author: Email: olga-baykova@list.ru

(C) 2018 Baykova et al. This is an Open Access article distributed under the terms of the Creative Commons Attribution License (http://creativecommons.org/licenses/by/2.0), which permits unrestricted use, distribution, and reproduction in any medium, provided the original work is properly cited.
} 


\section{Introduction}

The term "interference" is used in linguistic literature to refer to changes that occur in the speech of bilinguals as a result of the interaction of various language systems (Weinreich, 2000). It should be noted that a cognitive approach is used for the analysis of language interaction and the specific features of the functioning of language units under bilingualism, which leads to linguistic interference in the language as a system. The process of identifying the causes of interference from the cognitive perspective offers new ways to approach research on the speech phenomenon, as well as the issues of generation and perception of speech. U. Weinreich's description still serves as a classical definition of interference as "those instances of deviation from the norms of either language which occur in the speech of bilinguals as a result of their familiarity with more than one language" (Weinreich, 2000, pp. 22).

The problem of interference is one of the most complex issues related to linguistic interaction; it is therefore particularly important to investigate its workings on the example of the language of the Russian Germans in the Kirov region. The interaction of the Russian and German languages in the speech of German bilinguals results in the increasing invasion of the rules of one language system into the framework of the other, bringing about the socalled levelling of the interacting languages (cf. Serzhanova2006, pp. 195; Gardner-Chloros 1997; Myers-Scotton 1995; Poplack 1990; Rampton 1998; Shastri, Pratima Dave 2010; Becker 2006; Erofeeva 2010).

Thus, the present article aims to study the interfering influence of the system of the native German language on the non-native Russian language of German bilinguals. It enables us to conduct an integrated study of the communicative effect of accented speech. The next section discusses the methodological issues.

\section{Methodology}

The key purpose of this study is to examine the interference changes in the Russian speech of German bilinguals, living in the Kirov region, under the influence of German dialects.

It should be noted that the German ethnic group was formed in the Vyatka region in the $\mathrm{XX}$ century as a result of several waves of migrations - voluntary and forced ones. The first references to the Germans in the Vyatka region can be found in archival documents of XVII century where such names as Nemchinov, Nemchin (originated from the word "nemets" meaning a German in the Russian language) are mentioned several times (in the garrisons of the towns Urzhum, Yaransk, Malmyzh) (Baykova et al., 2016).

The manifestos of Catherine II initiated the first stage in 1762 and 1763 . When they came into force there began the so-called 'agricultural' immigration of Germans to Russia, namely, to the Vyatka Governorate. They were interested in developing the factory industry in the region, which required knowledge and skills. The second stage was connected to the forced removal of war prisoners in the Vyatka Governorate. The fact is that, during the Patriotic War of 1812 and the First World War, thousands of war prisoners from France, Saxony, Italy, Poland, Bavaria, Austria and Prussia were sent to Siberia via the Vyatka Governorate. The third stage is associated with the deportation of Russian Germans from the Volga region, Ukraine, and Kazakhstan.

According to statistics, currently, 1408 Russian Germans live in the Kirov region. The areas of residence: Verkhnekamsky district, Nagorskydistrict, Luzsky district, KirovoChepetsk District, and the city of Kirov (please refer to Figure 1 for a details of the region). 


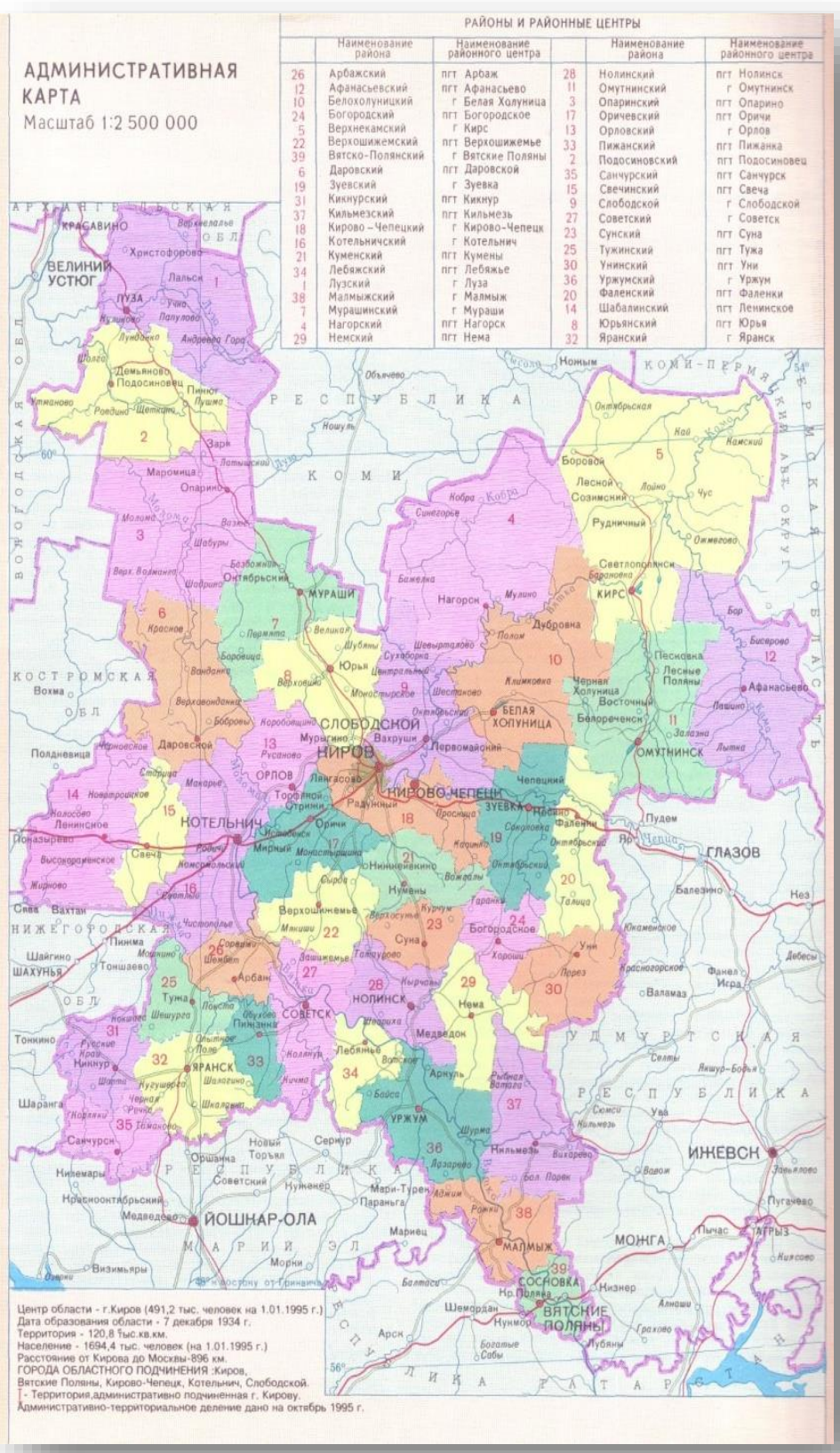

Figure 1: Administrative Map of Kirov Region

Source: Карта Кировской области, retrieved http://nakartemira.com/karta/kirovskaya-

\section{oblast.html}

They do not belong to the autochthonous ethnic groups. Till the XX century, representatives of this ethnic group did not comprise a unified ethnic group, unlike the Russian Germans living in the dense settlements in Ukraine, the Volga region, Transcaucasia, Saint Petersburg Governorate, Siberia and Central Asia. They were not peasants but qualified professionals and intellectuals. Their quite dense settlements appeared in the Vyatka region only in the middle of the $X X$ century.
The study of the Russian Germans in the Kirov region began in 1999, but the research is conducted around four main aspects of the functioning of the German dialects regarding the linguistic island. These aspects are historical-demographical, cultural, sociolinguistic and linguistic proper. Historicaldemographical aspect deals with obtaining and generalising different data, including statistical ones, in particular, when the Germans came to the Vyatka Governorate, how they settled geographically, the population composition: 
age structure and social status. Cultural aspect helps us follow the connection between speech facts of the island dialect speakers and their culture, ethnic awareness and attitude to the neighbouring ethnic groups. Sociolinguistic aspect helps us estimate the linguistic competence, define functioning fields of the German island dialects and esteem their practical value. And finally, the linguistic aspect proper establishes the level of informant's mastering the language (Baykova et al., 2014, pp. 1160).

Some of the observations presented in this paper provide an example of the fact that the native German language of Russian Germans influences the Russian language, which they mastered in changed social conditions

The principal objective of the study is the Russian speech of the Russian Germans, who were deported in the 1940s to the northern parts of the Kirov region and who now live in the villages of Sozimsky and Chernigovsky in Verkhnekamsky district of the given region (cf.Baykova 2017, pp. 44).To retrieve first-hand information, we had recorded 50 hours of speech of the Russian Germans living in the Kirov region. These recordings served as a material to study the processes of interaction between languages in the speech of bilinguals. Tape recordings constituted spontaneous monologicutterances and answers to questions on a variety of topics: biographical material, stories about relatives and acquaintances, about their experiences in the years of deportation, their impression of the Vyatka land, Vyatka people. The speech of the informants has different degrees of expressiveness depending on the topics and the contents of utterances. Thus, the obtained material produced $\mathrm{s}$ a more objective approach to the studied phenomena in the field of interlanguage interference and an opportunity to present it with sufficient clarity. While selecting the sound material we paid particular attention to the highest information capacity from historical, sociolinguistic, and proper linguistic aspects of the study. Most of the texts are spontaneous monologues interrupted by dialectologists' questions. Some texts constitute dialogues of the informants, Russian Germans at the age of 75-90 years who speak native German dialects and dialectologists, who make the recordings.

The language materials were used in the experiment on the perception of the Russian speech of the Russian Germans in the region under review. The purpose of the research was to analyse the impact of the sound system of the native German language on the system of the non-native - Russian language.

The participants of the experiment were the students-philologists of the $\mathrm{I}-\mathrm{V}$ courses of Vyatka State Humanities University (25 people), who completed a course of dialectology, history and theory of the modern Russian language and a course of dialectology, history and theory of the contemporary German language. After listening to the recorded speech, they were to analyse the linguistic material and give answers to questions according to a particular algorithm.

We used sound fragments lasting 30 seconds as experimental material. In the texts, there is no mention of those realities and facts that might suggest the nationality of the informants.

The experiment was conducted on personal computers in a programmed sequence using the program "VERSTEU", created in 1991 by the German scientists M. Knippschild and K. Sappok using the method developed by M. Krause, V. Ljublinskaja, K. Sappok in connection with the studies of dialect consciousness in modern Russia. Also, we used the technique of geographical definitions of dialect texts and their evaluation (Krause, Ljublinskaja and Sappok 2006, pp. 31-44; Makarova 1998). Sound files were played through headphones.

The experiment consisted of three tests. The first test was supposed to reveal how strong the relationship of the native German dialect of the informant and the Russian language is pronounced. The auditors had to identify the dialectal colouring of the speech heard, using four possible answers: "Russian literary language", "mild Russian dialect", "strongly 
pronounced Russian dialect", "hard to say". The second test used the same sound files, but the goal was more narrow, that is, to show that the native German language of the informants has an impact on the Russian language, which they mastered in the changed social conditions when they moved to the Russian-speaking region, and that interference makes itself felt like a foreign accent in the speech of a person who can speak two languages. The auditors were to determine whether this utterance was pronounced by a native speaker of Russian or some other language. Response options: "a native Russian speaker", "a speaker of another language", "hard to say". In the third test, while listening to the same audio files, the informants were to determine the level at which language interference was more pronounced. It is known to cover all language levels, but it is especially evident in phonetics. Is that so? This question can only be answered with the help of the third test of the experiment. The proposed answers were as follows: interference is expressed "in phonetics", "in vocabulary", "in grammar", "no changes to report".

The subjects were given 15 stimuli containing Russian speech of 15 Russian Germans of the Kirov region with a strongly or weakly pronounced interference. Each sound file was given a name for a brief entry in the computer, namely the initials of the Russian Germans. The results are discussed in the following section.

\section{Results and Discussion}

This research set out to look for the influence of the native German dialects of the Russian speech of German bilinguals. The results (tests 1, 2 and 3 ) and the insights gained from this study are analysed, discussed and presented in the form of tables (Tables 1, 2 and 3).

\section{Test No.1}

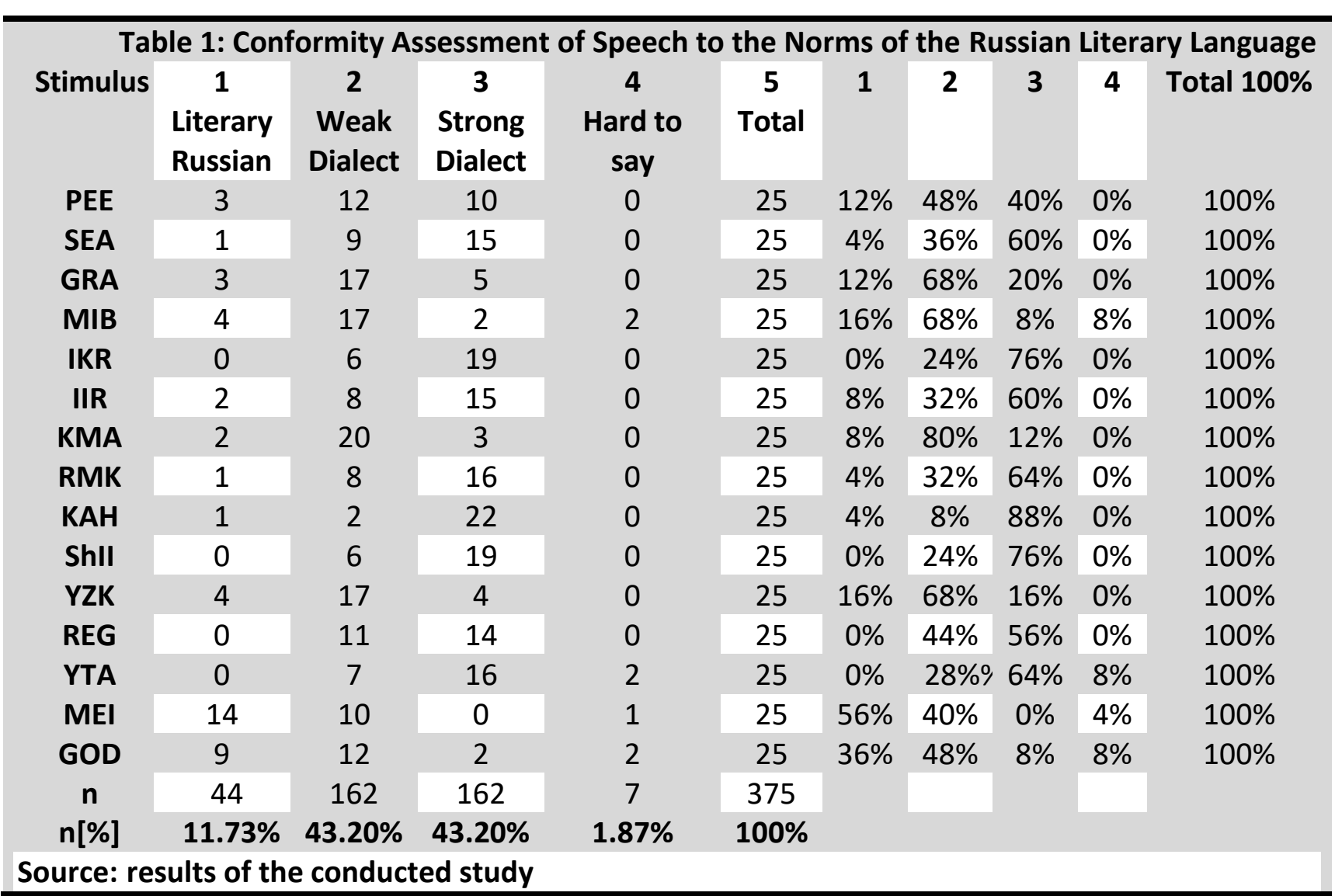

We had listened to 375 incentives (Table 1). $11.73 \%$ of the listened stimuli were attributed to the Russian literary language, $43.20 \%$ is a "weakly pronounced dialect" (this figure implies low interference), $43.20 \%$ constitutes a "pronounced dialect" (strongly pronounced interference). Only $1.87 \%$ of the answers are "hard to say." The highest percentage of the answer, that is, "literary Russian" is $56 \%$ on the audio fragment of the MEI speech; the highest 
percentage of the answer- "poorly pronounced dialect" is $80 \%$ on the sound fragment of KMA speech; the highest percentage of the answer- "strongly pronounced dialect" is $88 \%$ on the sound fragment of KAC speech.

The speed of choosing the answers should be taken into account because the subjects were asked not to wait until the end of the audio fragment, and to answer as quickly as possible. For this purpose, we used an oscillogram and a computer program "SONA" to beforehand presegment each sound extract of 30 seconds in length into ten identical pieces, which allowed using "VERSTEU" to fix the delay time of the reaction. Thus, we could obtain the ability to correlate the response of the auditors with the portion of the text that was necessary for decision-making. While the shortest possible response segment of "Russian literary language" - 04 - on the fragments of speech of YZK, MEI, GOD; the other shortest possible response segment of "mild dialect" was - 02 PEE. Besides, the shortest possible segment of the response "strongly pronounced dialect" is observed on fragment 02 - SEA, REG. Thus, one can understand that the subjects determined the foreign accent rather quickly.

\section{Test No. 2}

The second test (Table 2) used the same sound fragments, listening to which the subjects gave the following answers - "speech of a speaker of the Russian language", "speech of a speaker of another language", "hard to say". In this second test, the attention was focused on whether the stimuli under consideration belong to the Russian speakers or some other language.

\begin{tabular}{|c|c|c|c|c|c|c|c|c|}
\hline $\begin{array}{l}\text { Stimulu } \\
\mathbf{S}\end{array}$ & $\begin{array}{c}1 . \\
\text { The } \\
\text { Russian } \\
\text { language }\end{array}$ & $\begin{array}{c}2 \\
\text { Another } \\
\text { language }\end{array}$ & $\begin{array}{c}3 \\
\text { Hard to } \\
\text { say }\end{array}$ & $\begin{array}{c}4 \\
\text { Total }\end{array}$ & 1 & 2 & 3 & $\begin{array}{c}\text { Total }= \\
100 \%\end{array}$ \\
\hline PEE & 3 & 22 & 0 & 25 & $12 \%$ & $88 \%$ & $0 \%$ & $100 \%$ \\
\hline SEA & 9 & 15 & 1 & 25 & $36 \%$ & $60 \%$ & $4 \%$ & $100 \%$ \\
\hline GRA & 17 & 8 & 0 & 25 & $68 \%$ & $32 \%$ & $0 \%$ & $100 \%$ \\
\hline MIB & 18 & 4 & 3 & 25 & $72 \%$ & $16 \%$ & $12 \%$ & $100 \%$ \\
\hline IKR & 7 & 17 & 1 & 25 & $28 \%$ & $68 \%$ & $4 \%$ & $100 \%$ \\
\hline IIR & 2 & 23 & 0 & 25 & $8 \%$ & $92 \%$ & $0 \%$ & $100 \%$ \\
\hline KMA & 20 & 2 & 3 & 25 & $80 \%$ & $8 \%$ & $12 \%$ & $100 \%$ \\
\hline RMK & 1 & 24 & 0 & 25 & $4 \%$ & $96 \%$ & $0 \%$ & $100 \%$ \\
\hline КАН & 6 & 19 & 0 & 25 & $24 \%$ & $76 \%$ & $0 \%$ & $100 \%$ \\
\hline ShIl & 1 & 24 & 0 & 25 & $4 \%$ & $96 \%$ & $0 \%$ & $100 \%$ \\
\hline YZK & 12 & 11 & 2 & 25 & $48 \%$ & $44 \%$ & $8 \%$ & $100 \%$ \\
\hline REG & 0 & 25 & 0 & 25 & $0 \%$ & $100 \%$ & $0 \%$ & $100 \%$ \\
\hline YTA & 6 & 16 & 3 & 25 & $24 \%$ & $64 \%$ & $12 \%$ & $100 \%$ \\
\hline MEI & 12 & 10 & 3 & 25 & $48 \%$ & $40 \%$ & $12 \%$ & $100 \%$ \\
\hline GOD & 11 & 13 & 1 & 25 & $44 \%$ & $52 \%$ & $4 \%$ & $100 \%$ \\
\hline$n$ & 125 & 233 & 17 & 375 & & & & \\
\hline $\mathrm{n}[\%]$ & $32.26 \%$ & $62.13 \%$ & $5.61 \%$ & $100 \%$ & & & & \\
\hline \multicolumn{9}{|c|}{ Source: results of the conducted study } \\
\hline
\end{tabular}

For this, we had listened to 375 incentives. $32.26 \%$ of the listened stimuli correlated with the answer- "the native speaker of the Russian language" (the highest percentage of the answer was $80 \%$, the sound fragments of the KMA), $62.13 \%$ is "the carrier of another language" (the highest response rate was 100\% REG), $5.61 \%$ is "hard to say." 
Analysing the results of the first two tests (Tables 1 and 2), it should be noted that despite more than half a century residence in the Kirov region and the fact that the Russian language became the medium of communication in almost all spheres of interaction, crosslanguage interference is inherent in the speech of practically all informants. This interference is manifested through a foreign accent that is mutual overlapping of the systems of German and Russian languages in the speech of the informants. The subjects defined the following manifestations of a foreign accent in the listened to stimuli: 1) at the sound level due to the mismatch of the system of phonemes, positional variation and articulatory bases of native and non-native languages; 2 ) at the lexical level in the different nature of accent and prosodic laws in the Russian and German languages; 3) at the level of intonation due to the mismatch of intonational systems (violations in the phonetic structure of intonation patterns), and also due to deviation in the syntagmatic articulation of speech into the smallest syntagms and word by word pronunciation of the phrase, including emphasis on prepositions, conjunctions, particles.

\section{Test No. 3}

In the third test (Table 3), the subjects determined the level at which language interference is most pronounced: in phonetics, vocabulary, grammar, or no changes are observed.

\begin{tabular}{|c|c|c|c|c|c|c|c|c|c|c|}
\hline Stimulus & $\begin{array}{c}1 \\
\text { Phonetic } \\
\text { S }\end{array}$ & $\begin{array}{c}2 \\
\text { Vocabulary }\end{array}$ & $\begin{array}{c}3 \\
\text { Grammar - }\end{array}$ & $\begin{array}{c}4 \\
\text { No } \\
\text { changes }\end{array}$ & $\begin{array}{c}5 \\
\text { Total }\end{array}$ & 1 & 2 & 3 & 4 & $\begin{array}{c}\text { Total }= \\
100 \%\end{array}$ \\
\hline PEE & 17 & 0 & 6 & 2 & 25 & $68 \%$ & $0 \%$ & $24 \%$ & $8 \%$ & $100 \%$ \\
\hline SEA & 12 & 2 & 3 & 8 & 25 & $48 \%$ & $8 \%$ & $12 \%$ & $\begin{array}{l}32 \\
\%\end{array}$ & $100 \%$ \\
\hline GRA & 6 & 1 & 6 & 12 & 25 & $24 \%$ & $4 \%$ & $24 \%$ & $\begin{array}{l}48 \\
\%\end{array}$ & $100 \%$ \\
\hline MIB & 7 & 0 & 4 & 14 & 25 & $28 \%$ & $0 \%$ & $16 \%$ & $\begin{array}{l}56 \\
\%\end{array}$ & $100 \%$ \\
\hline IKR & 15 & 3 & 3 & 4 & 25 & $60 \%$ & $12 \%$ & $12 \%$ & $\begin{array}{l}16 \\
\%\end{array}$ & $100 \%$ \\
\hline IIR & 15 & 3 & 6 & 1 & 25 & $60 \%$ & $12 \%$ & $24 \%$ & $4 \%$ & $100 \%$ \\
\hline KMA & 3 & 2 & 7 & 13 & 25 & $12 \%$ & $8 \%$ & $28 \%$ & $\begin{array}{l}52 \\
\%\end{array}$ & $100 \%$ \\
\hline RMK & 12 & 1 & 11 & 1 & 25 & $48 \%$ & $4 \%$ & $44 \%$ & $4 \%$ & $100 \%$ \\
\hline КАН & 12 & 4 & 5 & 4 & 25 & $48 \%$ & $16 \%$ & $20 \%$ & $\begin{array}{l}16 \\
\%\end{array}$ & $100 \%$ \\
\hline Shll & 10 & 0 & 15 & 0 & 25 & $40 \%$ & $0 \%$ & $60 \%$ & $0 \%$ & $100 \%$ \\
\hline YZK & 4 & 3 & 6 & 12 & 25 & $16 \%$ & $12 \%$ & $24 \%$ & $\begin{array}{l}48 \\
\%\end{array}$ & $100 \%$ \\
\hline REG & 9 & 0 & 16 & 0 & 25 & $36 \%$ & $0 \%$ & $64 \%$ & $0 \%$ & $100 \%$ \\
\hline YTA & 11 & 1 & 6 & 7 & 25 & $44 \%$ & $4 \%$ & $24 \%$ & $\begin{array}{l}28 \\
\%\end{array}$ & $100 \%$ \\
\hline MEI & 10 & 0 & 5 & 10 & 25 & $40 \%$ & $0 \%$ & $20 \%$ & $\begin{array}{l}40 \\
\%\end{array}$ & $100 \%$ \\
\hline GOD & 13 & 0 & 5 & 7 & 25 & $52 \%$ & $0 \%$ & $20 \%$ & $\begin{array}{l}28 \\
\%\end{array}$ & $100 \%$ \\
\hline $\mathbf{n}$ & 156 & 20 & 104 & 95 & 375 & & & & & \\
\hline $\mathrm{n}[\%]$ & $42.66 \%$ & $5.33 \%$ & $26.67 \%$ & $25.34 \%$ & $100 \%$ & & & & & \\
\hline
\end{tabular}

For Test 3, we had listened to 375 incentives. $42.66 \%$ of the listened stimuli were attributed to phonetics, that is, the tested subjects determined that interference was expressed most clearly in phonetics (the highest percentage was $68 \%$ on the sound fragment of PEE); in the case of $5.33 \%$ - the interference is expressed in vocabulary (the highest 
percentage is $16 \%$ on the sound fragment of $\mathrm{KAH})$, for $26.67 \%$ - intervention is shown in grammar (the highest percentage is $64 \%$ on the sound fragment of REG) and for $25.34 \%$ - "no change" (the highest percentage is $56 \%$ on the fragment of MIB).

Based on these data, it can be argued that interference can cover all language levels, but especially phonetics, that is, the Russian speech on the lips of representatives of the German national minorities of the considered region acquires certain phonetic properties, associated with phonological and phonetic characteristics of each of the sound systems. The primary source of interference is the difference in the systems of interacting languages: different phonemic structure, rules for the positional realisation of phonemes, their compatibility, different intonation, different ratio of differential and integral signs, different grammatical categories and means of their expression.

The analysis of the summary table of the three tests (Tables 1, 2 and 3) of the experiment made it possible to draw the following conclusions:

Judging by the responses of the subjects, the Russian speech of only one informant-speaker (MEI - 56\% Russian literary language) is closer to Russian literary language. The speech of other informants-speakers contains interference in a varying degree. As described above, the interference covers all language levels. However, it is more noticeable in phonetics and gives the speech a foreign accent. Based on the responses of the subjects, phonetic interference prevails in the speech of $\mathrm{KAH}-76 \%$ (some other language), 48\% (phonetics). The auditors determined the speech of KAH as non-Russian, this is the result of phonetic interference in her speech. We find similar changes in the speech of Shll - 96\% (some other language), 40\% (phonetics), PEE $88 \%$ (some other language), 68\% (phonetics), the SEA - 60\% (some other language), $48 \%$ (phonetics), IKR - 68\% (another language), 60\% (phonetics), REG - 100\% (some other language), 36\% (phonetics).
Along with the phonetic changes in the speech of informants-speakers of the region under consideration, the auditors detected grammatical interference, which is expressed in the change of the system of declensions, conjugations, tense, word order, etc. Phonetic and grammatical interference is most pronounced in the Russian language of Shll 96\% (some other language), 40\% (phonetics), $60 \%$ (grammar), REG - 100\% (some other language), 36\% (phonetics), 64\% (grammar).

According to the auditors, lexical interference is not so clearly represented in the speech of the informants-speakers. It is typically expressed infrequently used elements of the German language, embedded in the Russian language, in the unconscious transition from the German language into Russian and back. These changes are most typical for the Russian speech of KAH - 16\% (vocabulary), IKR - 12\% (vocabulary), YZK $-12 \%$ (vocabulary).

Comments given below confirm that the native German language of the speakers influences the Russian language, which they mastered in the changed social conditions.

\section{Phonetics Review}

The most striking deviations in the system of the Russian consonantism and vocalism under the influence of their native German language in the Russian speech of the informants, the Russian Germans, are:

1. Consonants are pronounced more tensely in contrast to the consonants of the Russian language and consonants of the Vyatka regional dialect. Voiceless plosive consonants [p], [t], [k] are aspirated in the speech of the informants of the given region, which is a characteristic feature of the German language:

[p]olucháetsja- sound fragment (hereinafter referred to as SF) 32; [k]azaks[t]án- SF 4-1; I'gó[t]ami- SF 4-1; zhivý[t] - SF $5-1 ;[t] y ́[t]-S F$ 5-1.

About the use of the voiceless plosive $[k]$, the emergence of the affricate [kh] 
in the Russian speech of the informants is typical of the southern regions in Germany. In some cases, the informants pronounced [k] with a strong aspiration in the initial position, which is a distinctive feature that characterises a number of Swabian dialects. Thus, we can assume that dialectal peculiarities of the German language are transferred over to the Russian speech of the informants:

[kh]ózhitsu, [kh]artóshka- SF 2-

1; u[kh]áz, [kh]ogót - SF 1-1; jazy[kh]óm-SF 6-1; [kh]ák-SF7-

1; [kh]ártochki- SF 11-1; [kh]oróv- SF 12; [kh]ormá, [kh]ák-SF 14-1.

2. In these texts, we witnessed identification of palatalised and nonpalatalised consonants of the sound system of the Russian language with non-palatalised German consonants. It should be noted that in the system of phonemes of the German language there is no opposition "palatalised non-palatalised":

pís'ma, dévochkas, uchítel'-SF 32; vyselénii, soprotivlénie-SF 11; pochemý-to, vozili, obizhájus'SF 4-1; mobilizováli, némtsy, ljubim-SF 5-1; perevódchik- SF 6-1.

All the informants pronounce voiced consonants as half-voiced, which gives their speech a subdued character. This phenomenon is typical of the German voiced consonants. To confirm this statement along with the Russian texts, we also present German texts of the informants, except three informants who would not speak German for some particular reasons.

One should pay attention to the sound fragment of the fourteenth informantspeaker, in which the informant replaces voiced consonants with their voiceless counterparts. This gives us reason to assume that the Russian speech of this informant presents the distinctive features of the high German dialects, in particular, the Frankish dialect, in which there is no phonological opposition "voice voiceless".

3. Alveolar pronunciation of front lingual consonants, which is typical of the German language, is also characteristic of Russian speech of the informants. This is seen from the examples in the following texts:

dévochkas, frónt- SF 3-2; ne panikúite-SF 1-1; zavód, tút-SF 4-1; devát', gód-SF 5-1.

4. The pronunciation of midlingual consonant [ç], which is characteristic of the German language, on the position of backlingual [kh], which is characteristic of the Russian language:

u ní[c]-SF 5-1, SF 7-1; rússki[ç]-SF 61; nachetverý[c] - SF10-1; vsé[ç]-SF 14-1.

In these cases, they pronounced a more closed vowel than in the Russian literary language and the regional dialect.

5. Pronunciation of a uvular (or deeply backlingual) $[\mathrm{KH}]$, characteristic of the German language, on the position of the backlingual $[\mathrm{kh}]$ after the nonfrontlingual vowels:

otdy[KH]áli- SF 2-1; Na[KH]ói, vokzála[KH]-SF 1-1; botínochká[KH]SF 4-1; túfel'ká[KH]-SF 7-1.

6. There are individual cases of pronouncing nasal [ $\mathrm{\eta}]$, characteristic of the German literary language, on the position of the combinations [nk], [nk']: vále[n]ki, re[b'ón]kom - SF 12.

7. It is typical for the speech of the informants to pronounce alveolar nasal [n], which is characteristic of the German language on the position of frontlingual [n], [n'] of the Russian language:

[n]ás, po-[n]emétski-SF 3-2; [n]aródSF 1-1; [n]átsiiu- SF 4-1; [n]émtsy, mashi[n]ístom-SF 5-1; órde[n]-SF 61. 
8. Some pronunciation particularities of the informants are caused by the difference in the positional terms in Russian and German. First of all, it concerns consonant $/ \mathrm{j} /$ :

a. there is no $/ \mathrm{j} /$ in the absolute end of the word after frontlingual vowels:

$v[Y] s^{\prime} k^{\prime} i$ instead of vysókij- SF 12.

b. pronunciation of a consonant is more tense, instead of a combination "a soft consonant + j" before vowels: s máte[r'u] - SF 1-1.

9. The informants tend to pronounce vowels [e], [o] more closed in a stressed position, [e] is pronounced as [i], [o] as [u]:

n[i]mka instead of némka; sk[ú]t instead of skót-SF 3-2.

10. It is typical of the informants' speech to pronounce labialised frontlingual vowels [U], [u:], characteristic of the German language, instead of the vowel [y] of the Russian language. This phenomenon can be traced after the labial and labialdental consonants:

$v$ [y:] vy-SF 3-2; $m[y:] m y-S F$ 7-1.

The pronunciation of unstressed vowels in the Russian speech of the informants is different from the Russian literary language and the regional dialect. This allows us to make the following assumption: the variance is because in the standard German language there is no qualitative reduction of vowels in unstressed syllables. Therefore, the pronunciation of the informants, whose mother tongue is German, is close to spelling.

The German accent in pronunciation is characterised by deviations in the rhythmic structure of the word. These deviations are due to the difference like stress and prosodic laws in the Russian and German languages. The following phenomena can be observed in the speech of the informants:
- a more intense and strong pronunciation of the stressed syllable is evident for all the informants;

- a longer pronunciation of the open syllable at the end of the word:

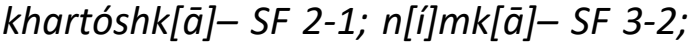
zárev[ō]-SF 3-1; pló[KHō]-SF 4-1.

- using secondary stress to emphasise an unstressed syllable (syllables):

botínochkàkh-SF 4-1; dònesénija-SF 61; túfel'kákh, stupén'kàmi-SF 7-1;

- a uniform pronunciation of unstressed syllables (usually post-tonic) can be observed in the Russian speech of native speakers of the German language:

nikóstóchék-SF 2-1; rússkímí-SF 3-2

There are individual cases of lack of unity in the pronunciation of words:

- emphasising prefixes, suffixes, components of a compound word with accents of different degrees:

pòsadili-SF 10-1; príostanóvit-SF 11-1;

- emphasising the start of a morpheme, beginning with a vowel, with the help of a glottal stop:

'obmén-SF 2-1; 'uchítel'-SF 3-2.

Especially this phenomenon is visible when two vowels are fused together at a morphemic junction:

samo'úchka-SF 3-2; speci'ál'no - SF 12.

However, it is problematic without further detailed research to say precisely where the deviation from the Russian literary language in the pronunciation of unstressed vowels comes from.

\section{Vocabulary Review}

The influence of the native German language on the non-native Russian language of the speakers can also be manifested at the lexical level. It is reflected in borrowing German words, used as a part (a component) of Russian words, constant German "inclusions" in the Russian language, frequent unconscious transition from Russian into German and vice versa, as a consequence of the fact that the 
Russian Germans of the studied region are bilingual. For them, it is equally accessible to express ideas both in Russian and German languages.

Using the method of the auditory analysis, we have found the following particularities in vocabulary:

- The use of borrowed from the German language words as a part (a component) of a Russian word:

[jan]evar-SF 2-2, [divisi]onnyj - SF 6-1.

- Constant, characteristic of the speech of ethnic Germans of the given region German "inclusions" in their Russian speech:

„...Nu, u nastambylacelaja nu ved' Gruppe (gruppa)..."-SF 3-2;

„...Vottak, nichts Gutes [nichegohoroshego]..." - SF 10-1.

- In the Russian speech of some informants, we can see the use of certain phrases in German.

In SF 7-1 the unconscious transition of $\mathrm{KAH}$ from Russian into German and vice versa confirms our assumption that in this case, it is easier for the informant to express her thoughts in a definite language:

In SF 1-1 YTA quotes a decree on the eviction of Russian Germans in German, in which it was published in a newspaper for Russian Germans:

“...Ja daval... gde-to jetagazetasohrani... hran... $v$ svjazi $s$ tem, chtoobnaruzhenytyshhi [=tysjachi] tausend und tausendeSpionen, Diversanten..."-SF 1-1.

In SF 12 on behalf of a little girl GRA recollects her mother's words and says as she remembered them, without translating them into Russian:

“... Aga, mama zahodit. Ja: "Oi, Mama liebe, Mama liebe..."Brosilas' na shejutoej, ona: „ $O$, Lischen, mein Kind, mein Kind, mein Kind!"[Plachet] I my zaplakali. I $\quad[$ V]se...
[v]seljudizaplakali..."-SF 12.

It can be assumed that these transitions from one language to another are most likely related to emotional excitement, to the experiences of informant-speakers.

\section{Grammar Review}

On the grammatical level, the influence of the native German language on the non-native Russian language of the speakers is manifested in the change of the systems of declension, conjugation, tense verb forms, word order, etc.

We have found the following phenomena in grammar:

1. The transference of grammatical gender, corresponding to the German language, into the Russian language:

“...Frontvezdeshla..." - SF 3-2.

In this case, the feminine gender of the German noun "die Front" is transferred to the Russian masculine word "front".

“...ono izodnogopal'toona by, jeto, sshilabol'shoida ipomen'she..."-SF 12.

Here, the masculine gender of the noun "der Mantel" (coat) is transferred to the Russian word of the middle genus "coat".

2. In SF 3-2 and SF 4-1, we assume that SEA and REG, the native Low German speakers, use the variant of the diminutive suffix -kes, which is characteristic of the Low German dialects, that is, in this case, we observe not only the influence of the German literary language but also German dialects.

3. Transferring the case governed by a verb of the German language to the case of the verbs of the Russian language:

“...on menjataknachalved'

obuchat'russkijjazyk..."-SF 3-2.

The German verb "unterrichten" (to teach) requires the accusative case without a preposition "Russischunterrichten", in contrast to the Russian language, which requires the dative case - "to teach the Russian language." 
4. In SF 12, we also observe the transference of the German grammatical phenomenon to the Russian speech of the informant. By analogy with the German language, in which, the preposition and the article in the dative and accusative cases change depending on the case, the noun does not have the ending of the dative case: "nachLalsk" (v Lal'sk to Lalsk), "in Lalsk" (v Lal'ske in Lalsk):

"...chtonadomne v Lal'sk, v Lal'sk, vi(di)sh', papa-to v Lal'sk..." -SF 12.

\section{Conclusion}

In general, observations of speech behaviour of the residents of the German nationality in the Kirov region show that Russian speech of Russian-German bilinguals is not uniform and varies from "almost accent-free" to "unnatural" for the ear of Russian monolinguals. Interference on the level of vocabulary and grammar may manifest itself not with all bilinguals, but phonetic interference - accent in varying degrees is present with all of the bilingual informants.

Deviations from the Russian orthoepic norms and the regional dialect are determined primarily by the violation of the opposition of voiceless and voiced, hard and soft consonants, as well as orthophonic features in the implementation of all frontlingual consonants, which gives the impression of a foreign accent. In the area of vocabulary and grammar, there are peculiarities, which are manifested in borrowings of German words used as a part (a component) of Russian words, constant German "inclusions" in the Russian language of ethnic Germans, frequent unconscious transition from Russian into German and vice versa, as well as changes in the systems of declension, conjugation, verb tense forms, word order, distortion of syntactic constructions, etc.

Thus, in summary, it should be noted that the correct pronunciation of some foreignlanguage, sound combinations and admittance of interference in the pronunciation of others suggest that the process of mastering the sound system of a second language is not instantaneous and that some foreign-language sound combinations begin to be pronounced according to a foreign language norm sooner, and others later. In this case, we observe the process of mixing the sound system of the surrounding language and the sound system of the recipient language. According to $\mathrm{V}$. A. Vinogradov, there arises a sequence of approximated systems that are in development and are increasingly approaching the system of the non-native language, used by speakers (Vinogradov, Koval' andPorkhomovskiy,1984). In other words, there is the emergence of a third, intermediate system, which coincides neither with German nor Russian languages and which performs in the minds of bilinguals an adaptive function to the surrounding language. After analysing the obtained data, it is possible to assert with confidence that under certain social conditions, when intensive contact with foreign language environment takes place, Russian Germans master the surrounding language. However, this interference is manifested at all levels of the non-native language and leads to a foreign accent in speaking, which has been experimentally established.

\section{References}

Baykova, O.V.

(2017).Russkiezaimstvovaniyavyazykeetnich eskikhnemtsevKirovskoyoblastikakrezul'tatli ngvokul'turnogokontaktirovaniya. [Russian borrowings in the language of ethnic Germans in the Kirov region as a result oflinguocultural contact]. Russian Linguistics, 41(1), pp. 43-60.

Baykova O. V., Obukhova O. N., Berezina Yu. V., Banin V. A., Kazakov A. V. (2016). Ethnic Identity and Language Variations of the Russian Germans in the Kirov Region, International Journal of Applied Linguistics \& English Literature, 5(6), pp. 152-157.

Baykova O. V., Berezina Yu. V. (2014). Variation in the Language of the Russian Germans in the Kirov Region in Alien Language Environment, Middle-East Journal of Scientific Research, 21 (7) pp. 1160-1162 
Becker, S. (2006). Kultur oder Sprache? Zur Rechtsprechung nach dem Bundesvertriebenengesetz (BVFG). Russlandsdeutsche Kultur: eine Fiktion? Schriftenreihe des Johannes-KünzigInstitutes. Band 7. Freiburg, pp. 109-143.

Erofeeva, T. I. (2010). Russkayaspontannayarech' tataroyazychnykhbilingvovPermskogokraya: zvuchashchayakhrestomatiya [spontaneous Russian speech of Tatar-speaking bilinguals of Permsky Krai: sounding reade]. Perm': Izdvo PGU

Gardner-Chloros, P. (1997). Code-Switching: Language Selektion in Three Strasbourg Department Stores. Sociolinguistics. A Reader and Coursebook. St. Petersburg: Martin's Press, INC., pp. 361-375.

Krause M., Ljublinskaja V. and Sappok K. (2006). Russian speaker's dialect image - a perceptional study. In: Filppula M. et al. (Eds.) Topics in dialectal variation. Joensuu: Joensuun yliopisto, 31-34.

Makarova L. N. (1998). Foneticheskie, morfologicheskie I

sintaksicheskieosobennostirusskikhgovorovKi rovskoyoblasti [Phonetic, morphological and syntactic features of Russian dialects of the Kirov region]. Kirov: Vyatka, pp. 244-255.

Myers-Scotton, C. (1995). Social motivation for code-switching: evidence from Africa. Oxford: Clarendon Press (Oxford University Press. IX), pp. 177.

Poplack, S. (1990). Variation theory and language contact: concepts, methods and data network on code-switching and language contact. Papers for the Workshop on Concepts, Methodology and Data. Strasbourg: John Benjamin Public Company, pp. 33-66.

Rampton, B. (1998). Language crossing and the redefinition of reality. Code-Switching in Conversation. Language, interaction and identity. London; New York: Routledge, pp. 290-317.

Serzhanova, Zh. A. (2004). Problemavyborajazykovogo variant naprimererechevogopovedenijanemcevSibiri. [The speech behaviour of the Germans exemplifies the problem of choosing a language variant in Siberia]. The Germans in Siberia: History, Language, Culture: Materials of the International Scientific Conference. Krasnojarsk: Izd-vo KGPU im. V. P. Astaf'eva, pp. 194-199.

Shastri, P. Dave (2010). Dave Communicative Approach to the teaching of English as a second language. Mumbai: Himalaya Publishing House

Vinogradov V. A., Koval' A. I. and Porkhomovskiy V. Ya. (1984).Sotsiolingvisticheskayatipologiya (Zapadnaya Afrika) [Sociolinguistic typology (West Africa)]. Moscow: Nauka

Weinreich U. (2000). Yazykovyekontakty: sostoyanie I problemyissledovaniya [Language contacts: state And problems of research]. Blagoveshchensk: Blagoveshchen. gumanitar. kolledzh. 